\title{
Translate to divide: control of the cell cycle by protein synthesis
}

\author{
Michael Polymenis ${ }^{1, *}$ and Rodolfo Aramayo ${ }^{2, *}$ \\ ${ }^{1}$ Department of Biochemistry and Biophysics, Texas A\&M University, College Station, TX 77843, USA. \\ ${ }^{2}$ Department of Biology, Texas A\&M University, College Station, TX 77843, USA. \\ * Corresponding Authors: Michael Polymenis; Tel: +1 979458 3259; Fax:+1 979845 4946; E-mail: polymenis@tamu.edu \\ Rodolfo Aramayo; Tel: +1 979862 4354; Fax: +1 979845 2891; E-mail: raramayo@tamu.edu
}

\begin{abstract}
Protein synthesis underpins much of cell growth and, consequently, cell multiplication. Understanding how proliferating cells commit and progress into the cell cycle requires knowing not only which proteins need to be synthesized, but also what determines their rate of synthesis during cell division.
\end{abstract}

doi: $10.15698 / \operatorname{mic} 2015.04 .198$

Received originally: 20.01.2015; in revised form: 04.03.2015,

Accepted 07.03.2015

Published 20.03.2015.

Keywords: protein synthesis, ribosome biogenesis, ribosome profiling, START, translational control.

\section{INTRODUCTION}

Experiments with proliferating populations of microbial strains, animal or plant cell lines, have rigorous expectations. Under the same culture conditions, cells ought to have the same properties and composition in every single experiment. The basic "metrics" of proliferating cells remain constant, even after many rounds of cell division [1, 2]. These metrics include cellular mass and volume, and macromolecular composition [1, 3]. The constancy of such parameters reflects the fundamental ability of cells to coordinate their growth with their division $[1,4,5]$. Balancing cell growth with cell division determines the overall rates of cell proliferation [4-8]. Despite the obvious significance of this phenomenon, how cells manage to coordinate their growth with their division remains largely mysterious.

Proteins are often the most abundant macromolecules in proliferating cells. For example, in steady-state cultures of the budding yeast Saccharomyces cerevisiae, the protein content ranges from $35 \%$ to $44 \%$ of all macromolecules, depending on culture conditions [3]. Furthermore, much of the proteome $(>20 \%)$ is dedicated to making ribosomes and translation factors, enabling cells to make more proteins [9]. On top of that, making ribosomal components and assembling them into functional ribosomes involves a dizzying array of molecular players and cellular processes [10-12]. Consequently, protein synthesis is viewed as a fundamental measure of cell growth. Decades ago, a founding father of cell cycle studies put it this way: "No sensible interpretation of cell growth can be made without a knowledge of the overall pattern of protein synthesis" [13].

In the following sections, we discuss the interplay of protein synthesis and cell division. Examples of translational control in embryonic and meiotic cell divisions have been covered comprehensively elsewhere [14, 15]. Here, the focus is on mitotic cell division and specifically on the G1 phase of the cell cycle, when cells commit to a new round of cell division. The examples discussed are mainly, but not exclusively, from the budding yeast $S$. cerevisiae. The discussion centers on un-perturbed, continuously dividing cells, and the impact of genetic, nutritional or chemical perturbations.

\section{OVERALL PATTERN OF PROTEIN SYNTHESIS IN THE CELL CYCLE}

In animal cells, protein synthesis is much lower in mitosis than in other cell cycle phases [16-18]. Mechanisms that enable translation of specific mRNAs in animal cells undergoing mitosis have been reviewed elsewhere [15, 19]. In contrast to the mitotic block in protein synthesis in animal cells, early studies indicated that budding yeast cells synthesize proteins, including ribosomal proteins, continuously during the cell cycle [20-23]. These experiments relied mostly on incorporation of labeled amino acids into polypeptides, which were then visualized after electrophoresis [21-23]. Hence, those early experiments sampled abundant, constitutively expressed proteins that make up the vast majority of the proteome [9, 24-26]. Obviously, transcrip- 
tional waves drive periodic synthesis of hundreds of proteins in the cell cycle $[27,28]$. Nonetheless, the bulk of cellular protein synthesis appears to proceed at an exponentially increasing rate in the cell cycle $[21,22]$. This conclusion was reinforced by monitoring the accumulation of constitutively expressed fluorescent proteins in single cells [29]. In addition, continuous monitoring of cell volume supports an exponential mode of increase in the cell cycle [30]. Therefore, it appears that budding yeast cells make proteins and grow exponentially. Based on buoyant mass as a metric of cell growth, the same can be said about the growth of diverse types of cells, from bacteria to mouse lymphoblasts, with heavier cells growing faster than lighter cells [31]. However, whether or not the growth of animal cells is exponential is still controversial [32-34].

An exponential mode of protein synthesis and growth is consistent with the existence of active mechanisms that sense some growth metric, perhaps somehow related to protein synthesis [7]. Such mechanisms would enable cells to monitor their growth and commit to a new round of cell division once their growth requirements are met $[6,7]$. As a result, cells that are born small stay longer in the G1 phase, until they grow enough to commit into and initiate a new round of cell division [4-7, 35]. In yeast, the point of commitment to a new round of cell division is called START [5]. START is marked molecularly by nuclear eviction of the Whi5p repressor $[29,36,37]$, a protein that functions analogously to the retinoblastoma gene product of animal cells $[38,39]$. Once cells pass through START in late G1, they will initiate and complete their division even if they encounter growth limitations $[4,5,35]$. To summarize simply, it seems that the bigger yeast cells get, the faster they make proteins and grow, propelling them to divide. This simple concept raises a series of key questions: What determines the rate of protein synthesis? How can the rate of protein synthesis be altered and what would the effects of such alterations be on the cell cycle? What are the RNA targets of translational control that affect cell cycle progression?

\section{INITIATE TO START?}

The rate of synthesis of any given protein depends on not only the concentration but also the translational efficiency of its mRNA. Discrepancies between the two parameters underpin translational control. It is often stated that control of translation in eukaryotic cells is exercised mainly at the initiation step, when ribosomes are recruited to mRNA [19]. As discussed in subsequent sections, additional layers of control may also change the rate at which proteins are made. Nonetheless, the initiation step remains a key control point of translation $[40,41]$. Ribosomal recruitment in eukaryotes usually involves recognition of a cap structure at the 5 '-end of the mRNA. The small (40S) ribosomal subunit loaded with initiator Met-tRNA and with the contribution of various initiation factors begins scanning the $5^{\prime}$-UTR of the mRNA for an AUG (or near-cognate start codons). In the process, it has to navigate past the secondary structure of the 5'-UTR [42] or initiation codons upstream of the main open reading frame [43]. Such features may affect

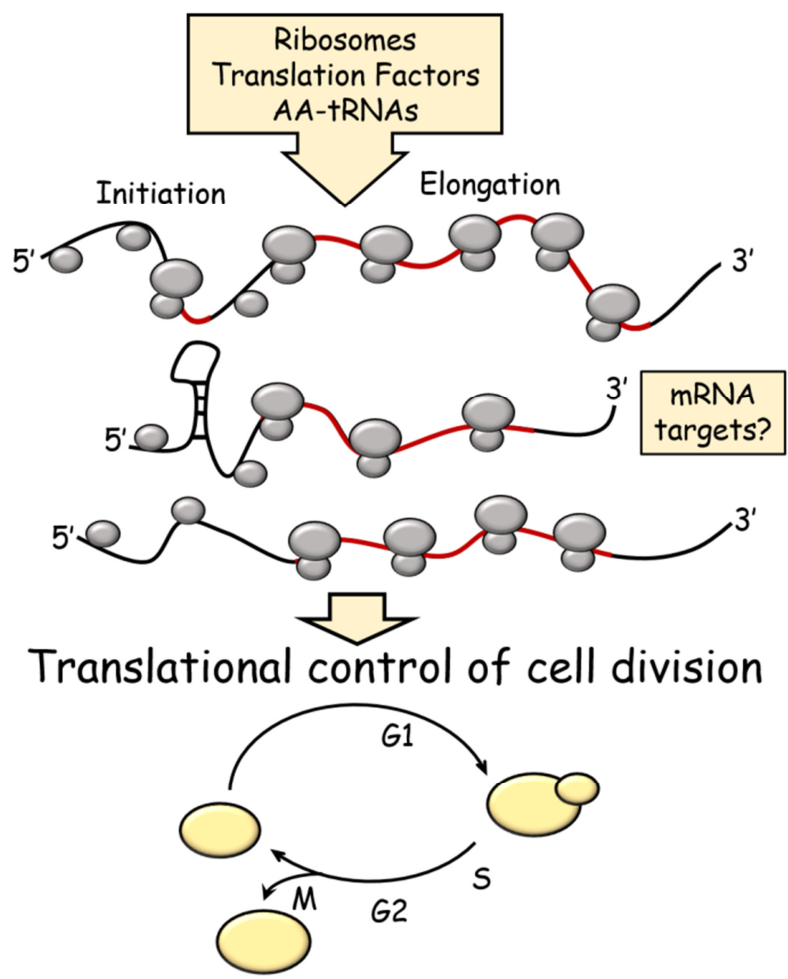

FIGURE 1: Schematic overview of the topics covered in this review. Open reading frames (ORFs) are shown in red.

recognition and initiation from the correct start codon [40, 41, 44].

The earliest genetic evidence for specific cell cycle effects due to translational control was the isolation of budding yeast conditional mutants in what turned out to be translation initiation factors [5]. One would expect that cessation of a continuous vital cellular function, such as initiation of translation, would simply arrest each cell at whichever point in the cycle that cell happened to be at the time. In an asynchronously proliferating cell population, this would manifest in a pattern of random arrests along the cell cycle [5]. Yet cell division cycle (cdc) genetic screens yielded mutants carrying temperature-sensitive, hypomorphic alleles of translation initiation factors, which did not display a random arrest at their non-permissive temperature. Instead, cells carrying cdc33 (encoding mRNA cap binding protein and translation initiation factor elF4E [45, 46]) or $c d c 63$ (encoding the $b$ subunit of translation initiation factor elF3 $[47,48])$ mutations arrest uniformly in the G1 phase of the cell cycle, unable to initiate DNA replication and a new round of cell division [35, 46, 49, 50]. A conditional methionyl-tRNA synthetase (mes1) mutant also arrests in the G1 phase of the cell cycle [51]. These classical genetic analyses suggested strongly that $\mathrm{G} 1$ transit is sensitive to translation initiation, more so than other phases of the cell cycle. This conclusion was strengthened when essential gene function was interrogated with a collection of titratable $\mathrm{TetO}_{7}$ promoter alleles for essential genes [52]. In 
addition to the elF4E and elF3b examples mentioned above, Yu et al. showed that inhibiting expression of elF2a, elF4A, elF2b, elF3i, or elF1 resulted in G1 arrest in yeast ([52]; and Table 1). Hence, impairing translation initiation in a number of ways, invariably and specifically also impairs the capacity of cells to initiate a new round of cell division.

If initiation of translation is important for commitment to division, then signaling pathways that control initiation of division may do so, at least in part, by regulating translation initiation. Mitogenic pathways would be expected to activate translation initiation, while pathways that convey anti-proliferative signals may inhibit translation initiation. The cardinal example for the former case is the Target of Rapamycin (TOR) pathway. How the TOR pathway activates initiation of translation and overall protein synthesis has been reviewed elsewhere $[53,54]$. Loss of TOR function was known to cause $G 1$ arrest in mammals $[55,56]$ and yeast $[53,57]$. Connecting the $G 1$ arrest with the effects of TOR on translation, however, was not obvious. In a landmark paper, it was shown that upon loss of TOR function in yeast, the cause of the $\mathrm{G} 1$ arrest was a direct consequence of a block in translation initiation [58]. De-repressing translation of the G1 cyclin Cln3p was sufficient to abrogate the G1 arrest of TOR-inhibited yeast cells [58]. TOR is not the only mitogenic pathway that activates translation initiation. The RAS/MAPK pathway in animals phosphorylates and increases the activity of elF4B [40,59]. Remarkably, phosphorylation of elF4B on the same residue is a common output of both the TOR and MAPK pathways [59], underscoring the significance of activating translation initiation for commitment to cell division. Conversely, upon stress or starvation it is not prudent to either initiate cell division or make many proteins. It turns out that phosphorylation of elF $2 \alpha$ is a conserved response from yeast to mammals that inhibits overall translation initiation, and it is an output of anti-mitogenic signals $[40,41,53,60]$.

\section{TRANSLATIONAL TARGETS (?) FOR COMMITMENT TO DIVISION}

The above examples suggest that translation initiation goes hand-in-hand with $\mathrm{G} 1$ progression and initiation of cell division. By and large, however, they do not answer how this is brought about. What are the relevant proteins important for G1 transit, whose synthesis is sensitive to limitations in translation initiation, and how do these proteins impinge on the machinery of cell division? In the case of the G1 cyclin Cln3p was mentioned above, Hall and colleagues replaced the long $5^{\prime}$-UTR of the yeast CLN3 mRNA with that of $U B / 4$, which is efficiently translated when TOR function is low [58]. Cells carrying this non-repressible CLN3 did not arrest in G1 when TOR function was inhibited by rapamycin [58]. Similarly, efficient translation of CLN3 enabled $\mathrm{G1}$ arrested $c d c 33$ cells, in which the activity of the elF4E is impaired (see Table 1), to initiate cell division [61]. The Whi3p RNA-binding protein, which sequesters CLN3 mRNA in cytoplasmic foci, may inhibit translation of CLN3 [62]. There is also a uORF in the $5^{\prime}$-UTR of the CLN3 mRNA [63]. We had proposed that the uORF lowers the number of scanning ribosomes that reach the downstream main AUG, especially when the ribosome content of the cell is low in poor media $[8,63]$. As predicted, inactivation of the UORF in CLN3 allowed cells growing in poor medium, with glycerol as the source for carbon, to accelerate completion of START [63]. Nitrogen limitation was also reported to repress translation of CLN3 [64]. In contrast, another study reported that 20 min after amino acid starvation, translation of CLN3 was up-regulated [43]. While this later discrepancy may simply reflect the different experimental setups, there is overall compelling evidence that synthesis of CIn3p, whose levels control the timing of START $[65,66]$, is regulated at least in part at the translational level. It should be noted, however, that all the examples above rest on comparisons between different conditions: with or without inhibitors of TOR $[58,63]$; mutant vs. wild type [61-63]; different nutrients $[43,63,64]$. It is important to stress that although CLN3 is a translational target, there is no evidence yet that it is targeted in a periodic manner in the cell cycle, in $\mathrm{G} 1$ or any other cell cycle phase.

It has been reported that CLN3 transcription oscillates early in the cell cycle $[67,68]$, but $C \ln 3 p$ protein levels were not evaluated in these studies. $C \ln 3 p$ is very unstable [69], and difficult to detect by immunoblotting. Early studies reported that $\mathrm{Cln} 3 p$ levels do not oscillate in the cell cycle [70]. Recently, however, more sensitive approaches from two independent studies showed that $\mathrm{Cln} 3 p$ protein is nearly absent in early G1 cells, but it gradually accumulates as cells approach START (Fig. 9 in [71], and Fig. 10 in [72]), without a corresponding increase in the mRNA levels of CLN3. The data from Thorburn et al. [71] and Zapata et al. [72] strongly implicate post-transcriptional mechanisms that control abundance of $\mathrm{Cln} 3 p$ in the cell cycle, perhaps due to control of its synthesis, degradation, or both. Both of these studies relied on centrifugal elutriation to isolate highly synchronous early G1 daughter cells, which were then sampled as they progressed in the cell cycle [71, 72]. Until analogous studies are performed with alternative synchronization methods, it is formally possible that the results reflect idiosyncrasies of elutriation. Note also that the CLN3 mRNA cannot possibly be the only physiological target of translational control for cell cycle progression. Cells lacking $C \ln 3 p$ are viable $[65,66]$ and they also respond as expected to nutrient limitations, reducing their size [38].

In other systems, the best example of a translational target important for initiation of mitotic cell division is the cyclin-dependent kinase inhibitor p $27^{\text {Kip1 }}$ in human cells, whose translation appears to be periodic in the cell cycle, decreasing at the G1/S transition [73-77]. Translational control of $\mathrm{p} 27^{\mathrm{Kip} 1}$ is complex, involving both cap-dependent and independent mechanisms $[75,77]$. However, because $\mathrm{p} 27^{\mathrm{Kip} 1}$ synthesis decreases at the $\mathrm{G} 1 / \mathrm{S}$ transition, this case of translational control cannot account for the postulated activating role of protein synthesis in triggering cell division. Other reported translational targets include the $\mathrm{G} 1$ cyclin D1 in mammals [78-80], and the G1/S cyclins E1 [81] and E2 [82] in mammals, and Cig2 in fission yeast [83] (reviewed in [84]). Trans-acting factors influencing translation 
TABLE 1. Cell cycle phenotypes of loss-of-function mutants in essential genes encoding protein synthesis and ribosome biogenesis factors in S. cerevisiae.

\begin{tabular}{|c|c|c|c|c|}
\hline $\begin{array}{c}\text { Systematic } \\
\text { name }\end{array}$ & $\begin{array}{c}\text { Standard name/ } \\
\text { alias }\end{array}$ & Function & $\begin{array}{l}\text { Cell cycle } \\
\text { phenotype }\end{array}$ & Ref. \\
\hline \multicolumn{5}{|c|}{ Translation Initiation Factors } \\
\hline YER165W & $P A B 1$ & Poly(A) binding protein & G1 & [136] \\
\hline YJROOTW & SUI2 & elF $2 \alpha$ & G1 & [52] \\
\hline YKR059W & TIF1 & elF4A & G1 & [52] \\
\hline YLR291C & GCD7 & elF2B $\beta$ & G1 & [52] \\
\hline YMR146C & TIF34 & elF3i & G1 & [52] \\
\hline YNL244C & SUI1/MOF2 & elF1 & G1 & [52] \\
\hline YOL139C & CDC33/TIF45 & elF4E & G1 & {$[45,46]$} \\
\hline YOR361C & PRT1/CDC63 & elF3b & G1 & {$[47,48]$} \\
\hline \multicolumn{5}{|c|}{ Translation Elongation Factors } \\
\hline YLR249W & YEF3 & eEF1B $\gamma$ & $\mathrm{G} 2 / \mathrm{M}$, other & [52] \\
\hline \multicolumn{5}{|c|}{ tRNA synthetases } \\
\hline YGR264C & MES1 & MetRS & G1 & [51] \\
\hline YLL018C & DPS1 & AspRS & G1 & [52] \\
\hline YOR335C & $A L A 1 / C D C 64$ & AlaRS & G1 & [50] \\
\hline YPL160W & CDC60 & LeuRS & G1 & [50] \\
\hline \multicolumn{5}{|c|}{ tRNA } \\
\hline$t Q(C \cup G) M$ & CDC65 & tRNA-GIn & G1 & [137] \\
\hline \multicolumn{5}{|c|}{ Ribosome biogenesis and assembly } \\
\hline YBLO04W & UTP20 & 18S rRNA biogenesis & other & [52] \\
\hline YBR142W & MAK5 & 605 ribosome subunit biogenesis & G1 & [52] \\
\hline YCL054W & SPB1 & AdoMet-dependent methyltransferase & G1 & [52] \\
\hline YCR057C & PWP2/UTP1 & 18S rRNA biogenesis & G1 & {$[108,138]$} \\
\hline YDL031W & DBP10 & $40 \mathrm{~S}$ biogenesis and $35 \mathrm{~S}$ pre-rRNA processing & G1 & [52] \\
\hline YDL060W & TSR1 & 20S pre-rRNA processing & G1 & [52] \\
\hline YDL148C & NOP14/UTP2 & $18 \mathrm{~S}$ rRNA biogenesis & G1 & [138] \\
\hline YDL153C & SAS10/UTP3 & 18S rRNA biogenesis & G1, other & {$[52,138]$} \\
\hline YDL166C & FAP7 & $20 S$ pre-rRNA processing & G1 & [52] \\
\hline YDR060W & MAK21 & 605 ribosome subunit biogenesis & G1 & [52] \\
\hline YDR091C & RLI1 & Ribosome biogenesis & G1 & [52] \\
\hline YDR324C & UTP4 & 18S rRNA biogenesis & G1 & [138] \\
\hline YDR398W & UTP5 & 18S rRNA biogenesis & G1 & {$[52,138]$} \\
\hline YDR449C & UTP6 & 18S rRNA biogenesis & G1 & [138] \\
\hline YER006W & NUG1 & Export of 605 ribosomal subunits from the nucleus & G1 & [52] \\
\hline YER082C & UTP7 & 18S rRNA biogenesis & G1 & {$[52,138]$} \\
\hline YER127W & LCP5 & 18S rRNA maturation & G1 & [52] \\
\hline YFLOO2C & SPB4 & 605 ribosome biogenesis & G1 & [52] \\
\hline YGROGOW & UTP22 & 18S rRNA biogenesis & G1 & [52] \\
\hline YGR103W & NOP7 & $60 \mathrm{~S}$ ribosome subunit biogenesis & G1 & [52] \\
\hline YGR128C & UTP8 & 18S rRNA biogenesis & G1 & {$[52,138]$} \\
\hline YGR245C & SDA1 & 605 ribosome biogenesis and actin organization & G1 & [52] \\
\hline YHRO72W-A & NOP10 & $18 \mathrm{~S}$ rRNA maturation & $\mathrm{G} 2 / \mathrm{M}$ & [52] \\
\hline YHR085W & IPI1 & 35 s pre-rRNA processing & G1 & [52] \\
\hline YHRO88W & RPF1 & Export of 605 ribosomal subunits from the nucleus & G1 & [52] \\
\hline YHRO89C & GAR1 & Modification and cleavage of the $18 \mathrm{~S}$ pre-rRNA & other & [52] \\
\hline YHR143W-A & RPC10 & RNA polymerase subunit common to RNA polymerases I, II, and III & $\mathrm{G} 2 / \mathrm{M}$ & [52] \\
\hline YHR196W & UTP9 & $18 \mathrm{~S}$ rRNA biogenesis & G1 & {$[52,138]$} \\
\hline YJL033W & HCA4 & 18S rRNA biogenesis & G1 & [52] \\
\hline YJLO69C & UTP18 & 18S rRNA biogenesis & G1 & [52] \\
\hline YJL109C & UTP10 & 18S rRNA biogenesis & G1 & [138] \\
\hline YJROO2W & MPP10 & 18S rRNA biogenesis & G1, other & [52] \\
\hline YKLOO9W & MRT4 & Ribosome assembly & G1 & [52] \\
\hline YKLO99C & UTP11 & $18 \mathrm{~S}$ rRNA biogenesis & G1 & {$[52,138]$} \\
\hline YKL172W & $E B P 2$ & $25 \mathrm{~S}$ rRNA maturation & G1 & [52] \\
\hline YLLOO8W & DRS1 & DEAD-box protein, 605 ribosomal subunits & G1 & [52] \\
\hline YLR002C & NOC3 & $60 \mathrm{~S}$ ribosome subunit biogenesis & $\mathrm{G} 2 / \mathrm{M}$ & [52] \\
\hline YLR009W & $R L P 24$ & $60 \mathrm{~S}$ ribosome subunit biogenesis & G1 & [52] \\
\hline YLR129W & DIP2 & 18S rRNA biogenesis & G1 & {$[52,138]$} \\
\hline YLR167W & RPS31 & Ribosomal protein & G1, other & [52] \\
\hline YLR175W & CBF5 & Pseudouridine synthase & other & [52] \\
\hline YLR186W & EMG1 & Methyltransferase for rRNA & G1 & [52] \\
\hline YLR222C & UTP13 & 18S rRNA biogenesis & G1 & [138] \\
\hline YLR276C & DPB9 & DEAD-box helicase, $27 \mathrm{~S}$ rRNA processing & G1 & [52] \\
\hline
\end{tabular}


TABLE 1. Cell cycle phenotypes of loss-of-function mutants in essential genes encoding protein synthesis and ribosome biogenesis factors in S. cerevisiae.

\begin{tabular}{|c|c|c|c|c|}
\hline \multicolumn{5}{|c|}{ PLEASE SEE THE BEGINNING OF THE TABLE ABOVE. } \\
\hline $\begin{array}{l}\text { Systematic } \\
\text { name }\end{array}$ & $\begin{array}{c}\text { Standard name/ } \\
\text { alias }\end{array}$ & Function & $\begin{array}{l}\text { Cell cycle } \\
\text { phenotype }\end{array}$ & Ref. \\
\hline \multicolumn{5}{|c|}{ Ribosome biogenesis and assembly } \\
\hline YML093W & UTP14 & 18S rRNA biogenesis & G1 & {$[52,138]$} \\
\hline YMR093W & UTP15 & 18S rRNA biogenesis & G1 & [138] \\
\hline YMR128W & ECM16 & DEAD-box helicase, $18 \mathrm{~S}$ rRNA synthesis & G1 & {$[52]$} \\
\hline YMR290C & HAS1 & Helicase, biogenesis of $40 \mathrm{~S}$ and $60 \mathrm{~S}$ ribosome subunits & G1 & [52] \\
\hline YNL113W & RPC19 & RNA polymerase subunit common to RNA polymerases I and III & G1 & [52] \\
\hline YNL124W & $N A F 1$ & pre-rRNA processing & $\mathrm{G} 1$ & {$[52]$} \\
\hline YNL163C & RIA1 & $80 \mathrm{~S}$ ribosome assembly & $\mathrm{G} 1$ & [52] \\
\hline YNL207W & RIO2 & $40 \mathrm{~S}$ ribosome subunit biogenesis & $\mathrm{G} 1$ & [52] \\
\hline YNR038w & DPB6 & DEAD-box helicase & G1 & [52] \\
\hline YNR053C & NOG2 & 605 ribosome subunit biogenesis & $\mathrm{G} 1$ & {$[52]$} \\
\hline YOLO1OW & $R C L 1$ & 18S rRNA maturation & G2/M, other & {$[52]$} \\
\hline YOR078W & BUD21/UTP16 & 18S rRNA biogenesis & G1 & {$[138]$} \\
\hline YOR119C & $R I O 1$ & $40 \mathrm{~S}$ ribosome subunit biogenesis & other & {$[52]$} \\
\hline YOR210W & $R P B 10$ & RNA polymerase subunit common to RNA polymerases I, II, and III & G1 & [52] \\
\hline YOR224C & RPB8 & RNA polymerase subunit common to RNA polymerases I, II, and III & G1 & [52] \\
\hline YOR294W & RRS1 & Export of 605 ribosomal subunits from the nucleus & G1, other & [52] \\
\hline YOR340C & RPA43 & RNA polymerase I subunit & $\mathrm{G} 1$ & [52] \\
\hline YOR341W & RPA190 & RNA polymerase I subunit & G1 & [52] \\
\hline YPL012W & $R R P 12$ & Export of ribosomal subunits from the nucleus & G1 & [52] \\
\hline YPLO43W & NOP4 & $27 \mathrm{~S}$ rRNA processing, $60 \mathrm{~S}$ ribosome subunit biogenesis & G1, other & [52] \\
\hline YPLO93W & NOG1 & $60 \mathrm{~S}$ ribosome subunit biogenesis & G1 & [52] \\
\hline YPL126W & NAN1 & 18S rRNA biogenesis & G1 & {$[52,138]$} \\
\hline YPL211W & NIP7 & $60 \mathrm{~S}$ ribosome subunit biogenesis & G1, other & {$[52]$} \\
\hline YPL217C & BMS1 & $40 \mathrm{~S}$ synthesis and $35 \mathrm{~S}$ pre-rRNA processing & G1 & {$[52]$} \\
\hline YPL266W & DIM1 & 18S rRNA dimethylase & G1 & [52] \\
\hline YPR016C & TIF6/CDC95 & elF6 & G1 & [52] \\
\hline YPR110C & $R P C 40$ & RNA polymerase subunit common to RNA polymerases I and III & G1 & [52] \\
\hline YPR144C & UTP19 & Maturation and nuclear export of $40 \mathrm{~S}$ ribosomal subunits & G1 & [52] \\
\hline
\end{tabular}

initiation of these targets include the helicase DDX3 for cyclin E1 [81] and Ded1 for Cig2 [83]. It is not clear, however, if translation of these cyclins is periodic in cycling cells. Alternatively, their translational regulation may be an output of a continuous process that affects their overall levels. The levels of these cyclins may oscillate in the cell cycle for other reasons, such as mechanisms that control mRNA levels and protein degradation. Overall, there is a critical gap in our understanding of the role of translational control in mitotic cell cycle progression, especially in G1 progression and commitment to division. There have not been any studies that directly and systematically looked for mRNAs that are translated differentially in the G1 phase, in cycling, un-perturbed cells.

\section{START ON CYCLOHEXIMIDE}

After the initiation step, the rate of translation depends on the concentration and activity of translating ribosomes that elongate the nascent polypeptides. If elongation of protein synthesis is inhibited, then what are the consequences on cell cycle progression? This question was first tackled pharmacologically, monitoring cell cycle progression in the presence of varying doses of cycloheximide [35, 85-87]. Cycloheximide inhibits the translocation step in eukaryotic $80 \mathrm{~S}$ ribosomes, blocking translational elongation [88]. Increasing doses of cycloheximide increase the population doubling time, mostly because cells spend more time in the G1 phase of the cell cycle [35, 85]. Cycloheximide also affects size homeostasis. In budding yeast, cycloheximide reduces the newborn cell size [35, 85] and the rate at which cells increase in size [89]. It also increases the critical size threshold for START $[85,89]$. These changes account for the increase in the duration of the G1 phase upon treatment with cycloheximide. The effects of cycloheximide support the notion that a critical rate of protein synthesis is required for G1 transit and completion of START in budding yeast [86] and animal cells [90, 91]. The reports that interrogated cycloheximide's effects on G1 progression have been influential. They have often been taken to imply a requirement for the continuous synthesis of unstable protein(s), whose rate of synthesis parallels overall protein synthesis rates and cell growth. Identifying those proteins and how they affect the cell division machinery would then hold the promise of explaining molecularly how cells couple their growth with their division [90, 91]. Various such candidate proteins have been proposed over the years. However, there is no report of a protein whose levels increase due to cell cycle-dependent translational control, as cycling cells approach START [7].

\section{RIBOSOME MAKES PROTEIN MAKES CELLS?}

Ribosomes are the complex macromolecular machines that catalyze protein synthesis. Hence, changing the concentra- 
tion of functional ribosomes in the cell is expected to change the overall rates of protein synthesis.

Bacterial cells grown under conditions that favor fast growth and proliferation (i.e., "rich" media) have more ribosomes than those propagated in "poor" media [92]. These observations suggest that the rate of protein synthesis in bacteria is controlled mostly by ribosome numbers [93]. Although growth rate does not seem to affect significantly the fraction of active ribosomes in the cell $(\approx 80 \%)$ or their activity [94], recent observations suggest that even in rich media bacterial ribosomes do not function at maximal elongation rates [95]. Hence, translation rates may be adjusted to proliferation rates by means other than ribosome content.

In budding yeast, although protein synthesis rates decrease with decreasing growth rates, there is no proportional decrease in the number of ribosomes per cell [96, 97]. For example, a 10-fold drop in growth rate is only accompanied by a 2 -fold drop in the number of ribosomes per cell (see Table 4 in [96]). On the other hand, synthesis of ribosomal components is inhibited as cells begin to exhaust the available nutrients and prepare to enter stationary phase [98], or upon amino acid starvation [99]. Apparently, both the activity and the number of ribosomes may be affected in yeast as a function of growth rate.

In cycling, unperturbed yeast cells, synthesis of ribosomal components is not cell cycle dependent [10, 22, 23]. Interfering with ribosome biogenesis, however, affects cell cycle progression dramatically. In yeast, 59 of a total of 78 ribosomal proteins of cytoplasmic ribosomes are encoded by pairs of very similar or identical paralogous genes [100]. Mutants carrying single deletions of those ribosomal protein genes are usually viable [101]. Many of these deletion strains have a small overall cell size $[102,103]$. A small overall cell size is also characteristic of cells lacking Sfp1p, a transcriptional activator of ribosome biosynthesis and ribosomal protein genes [89]. Cells lacking Sfp1p are born very small [104], and their growth rate is about half of that of wild type cells [71, 104]. As a result, the duration of the G1 phase of the cell cycle is greatly increased in $s f p 1 \Delta$ cells [ 71 $89,104]$. Still, the smaller critical size threshold of $s f p 1 \Delta$ cells and the smaller overall size of ribosomal protein mutants led Tyers and colleagues to propose that ribosome biogenesis inhibits START in wild type cells $[6,89]$. In this model, ribosome biogenesis sets the critical size threshold for START, while translation rates of functional ribosomes enable the cells to pass that threshold $[6,89]$. This model appears paradoxical and counterintuitive, especially since in animals ribosome biosynthesis is thought to promote cell proliferation and cancer [105]. But another finding, that ribosomal proteins may function as haploinsufficient tumor suppressors in animals, appeared to offer support for a negative role of ribosome biogenesis in cell division [106]. However, it was subsequently reported that such effects may be due to cell non-autonomous routes [107]. Furthermore, the following observations argue against the notion that ribosome biogenesis has a general inhibitory role for the initiation of division: First, inhibition of ribosome maturation delays START [108]. Second, despite their small cell size, most ribosomal protein mutants have a longer G1 phase [104, 109, 110]. Third, loss-of-function of the vast majority of essential ribosome biogenesis factors leads to G1 arrest (see Table 1 and [52]). The most straightforward interpretation of the evidence outlined above is that ribosome biogenesis promotes initiation of cell division in budding yeast.

Even when there is a G1 delay due to loss of a ribosomal protein, G1 variables such as birth and critical size of cells lacking individual ribosomal proteins are not uniform, differing qualitatively and quantitatively [104, 109, 111]. Furthermore, although a delay in $\mathrm{G} 1$ is the most common phenotype upon loss of a ribosomal protein, this phenotype is not universal. In several cases, there is no cell cycle phenotype, or a G2/M block is observed instead [104, 110]. The basis of all those differences in ribosomal protein mutant phenotypes related to the cell cycle is not clear. Do they reflect specialized translational roles of some ribosomes? Are overall translation rates affected? Is the concentration of ribosomes, their composition, their activity, localization in the cell (or any combination of the above) that is affected? Examples of specialized ribosomal functions abound [112-115], leading some to speculate on the existence of a "ribosome code" [116]. There are even cases of extraribosomal roles for ribosomal proteins [117]. Regardless of the answers to the above questions, it is imperative that the relevant mRNA substrates affected in each ribosomal protein mutant must be identified, to understand how cell cycle progression might be impacted. However, as is the case for wild type cells (see INITIATE TO START? above), there are no systematic surveys of mRNAs that are translated differentially in the cell cycle in ribosomal protein mutants.

\section{THE OTHER RIBOSOME SUBSTRATES: TRNAS}

For the ribosome to elongate at its maximal rate, all its substrates must be present at saturating concentrations. This includes the aminoacyl-tRNAs and the various elongation factors [95]. Inhibition of elongation factor eEF2 may be one way that protein synthesis is inhibited in animal cells in mitosis [118]. However, unlike the numerous examples of perturbations in translation initiation factors that lead to $\mathrm{G} 1$ arrest in yeast (Table 1), there is very little analogous evidence for translation elongation factors affecting cell cycle progression. The only reported example is from a large survey of essential genes, reporting that blocking expression of eEF1By in yeast leads to cell cycle arrest in mitosis ([52], see Table 1).

Translation elongation rates may be affected by several parameters [119], including the supply and demand for each tRNA. The genetic code is essentially universal. One and the same codon does not code for different amino acids in different organisms. The code, however, is also degenerate. Most amino acids can be specified by more than one codon. A decades-old speculation has been that codons for an amino acid that are used more frequently in an organism would be translated more rapidly than codons for the same amino acid that are rarely used [120]. Differ- 
ences in codon usage were difficult to test until the advent of ribosome profiling. Sequencing ribosome-protected mRNA fragments allows estimates of ribosome residency on individual codons [43]. Several analyses that included the original ribosome profiling datasets in yeast [43] have examined various parameters, including codon usage, and reached contradictory conclusions [42, 119, 121-126]. Nonetheless, common codons may be translated faster than rare ones in yeast [127]. Modulating which codon is used and the effective concentration of its corresponding tRNA may be a way to influence translation elongation rates both within an mRNA, and across the transcriptome [128]. Surveying codon usage across each codon and tRNA availability revealed that in highly expressed mRNAs rare codons are more prevalent in the first 30-50 codons, slowing down and crowding ribosomes along that stretch [129]. It was proposed that this slow "ramp" is a mechanism that promotes faster translation downstream, by alleviating ribosome "traffic jams" along the mRNA [129]. Furthermore, it turns out that once a particular codon has been used, it will also be used more frequently whenever the same amino acid is encoded downstream in that mRNA [130]. Based on these observations, it was theorized that tRNAs do not diffuse away from the ribosome once they are expelled from it. Instead, the same tRNA for a codon specifying the repeating amino acid is re-charged and channeled for re-use, enabling translation to proceed faster than tRNA diffusion [130].

The examples outlined above illustrate how alterations in the supply and demand for each tRNA could impact translation rates. The pertinent question for this review, however, is whether such mechanisms could lead to translational control during the cell cycle. Remarkably, a recent study proposed exactly that kind of regulation, based on codon usage [131]. Optimal codon usage is more prevalent in mRNAs expressed in the G1 phase of the cell cycle, implying that the corresponding mRNAs are translated more efficiently [131]. Interestingly, it has been known for decades that loss-of-function mutations in several tRNA synthetases, and even in a tRNA gene, lead to G1 arrest in yeast (see Table 1). Optimizing translation elongation rates in $\mathrm{G} 1$ through codon usage is an exciting possibility. But a correlation is not causation, and the above predictions must await experimental validation, measuring the translational efficiencies of the putative mRNA targets in cycling cells. On a cautionary note, a recent study in mouse embryonic stem cells reported that translation elongation rates were not only independent of codon usage, but also very similar across different mRNAs [132]. Likewise, another study in yeast reported that the rate of translation elongation and translational efficiency were not affected by tRNA abundance, and codon translation rates were not correlated with codon bias [133]. Hence, these issues remain controversial and there might be some time before the dust settles.

\section{DIVIDE TO TRANSLATE?}

Implicit in the discussion of all the examples mentioned above is the notion that cell growth and protein synthesis drive cell cycle progression, not the other way around. This is generally the case, established in classic and particularly lucid experiments by Hartwell and colleagues [4, 5, 35]. However, there are also some changes in the pattern of growth once cell cycle progression is blocked [134, 135]. Does that mean that progressing in the cell cycle might also affect the translational control of specific mRNAs? The answer is a resounding yes. Ruggero and colleagues examined by ribosome profiling human cells arrested by thymidine block (G1 and S phases) and nocodazole treatment (G2 phase) in the cell cycle, reporting extensive translational control of numerous mRNAs [17]. Interestingly, this work revealed functional clusters of co-regulated mRNAs. Translational control may be used to coordinate expression of specific cellular machines and processes [17]. These experiments are very important, answering how cell division controls translation. However, they do not answer how translation controls cell division.

\section{OUTLOOK}

The role of protein synthesis and translational control has a long history in the cell cycle field. The pioneering experiments of decades ago were incisive, but also largely descriptive. Since then, progress has been incremental and focused on a limited number of putative mRNA translational targets. Identifying all the mRNAs that are under periodic translational control in cycling cells is an obvious and necessary goal. Given the transformative methodologies now available and the current pace of progress, it is only a matter of time before we know how protein synthesis drives cell cycle progression.

\section{ACKNOWLEDGMENTS}

Work in the authors' laboratories has been supported with grants from the National Science Foundation (MCB0818248 to M.P.) and the National Institutes of Health (GM58770 to R.A.). The open access publishing fees for this article have been covered by the Texas A\&M University Online Access to Knowledge (OAK) Fund, supported by the University Libraries and the Office of the Vice President for Research.

\section{CONFLICT OF INTEREST}

The authors declare no conflict of interest.

\section{COPYRIGHT}

(C) 2015 Polymenis and Aramayo. This is an open-access article released under the terms of the Creative Commons Attribution (CC BY) license, which allows the unrestricted use, distribution, and reproduction in any medium, provided the original author and source are acknowledged. 
Please cite this article as: Michael Polymenis and Rodolfo Aramayo (2015). Translate to divide: Control of the cell cycle by protein synthesis. Microbial Cell 2(4): 94-104.

doi: $10.15698 / \mathrm{mic} 2015.04 .198$

\section{REFERENCES}

1. Neidhardt FC, Ingraham JL, Schaechter M (1990). Physiology of the bacterial cell. Sinauer Associates, Inc, Sunderland, Massachusetts.

2. Meyer HP, Kappeli O, Fiechter A (1985). Growth control in microbial cultures. Annual review of microbiology 39:299-319.

3. Lange HC, Heijnen JJ (2001). Statistical reconciliation of the elemental and molecular biomass composition of Saccharomyces cerevisiae. Biotechnology and bioengineering 75(3): 334-344.

4. Johnston GC, Pringle JR, Hartwell LH (1977). Coordination of growth with cell division in the yeast Saccharomyces cerevisiae. Experimental cell research 105(1): 79-98.

5. Pringle JR, Hartwell, L.H. (1981). The Saccharomyces cerevisiae Cell Cycle. The Molecular and Cellular Biology of the Yeast Saccharomyces. Cold Spring Harbor Laboratory Press; pp 97-142.

6. Jorgensen $P$, Tyers $M$ (2004). How cells coordinate growth and division. Current biology : CB 14(23): R1014-1027.

7. Turner JJ, Ewald JC, Skotheim JM (2012). Cell size control in yeast. Current biology : CB 22(9): R350-359.

8. Polymenis M, Schmidt EV (1999). Coordination of cell growth with cell division. Current opinion in genetics \& development 9(1): 76-80.

9. Liebermeister W, Noor E, Flamholz A, Davidi D, Bernhardt J, Milo R (2014). Visual account of protein investment in cellular functions. Proceedings of the National Academy of Sciences of the United States of America 111(23): 8488-8493.

10. Warner JR (1999). The economics of ribosome biosynthesis in yeast. Trends in biochemical sciences 24(11): 437-440.

11. Fatica A, Tollervey D (2002). Making ribosomes. Current opinion in cell biology 14(3): 313-318.

12. Venema J, Tollervey D (1999). Ribosome synthesis in Saccharomyces cerevisiae. Annual review of genetics 33(1): 261-311.

13. Mitchison JM (1971). Cell Growth and Protein Synthesis. The Biology of the Cell Cycle. Cambridge University Press; pp 129.

14. Brar GA, Yassour M, Friedman N, Regev A, Ingolia NT, Weissman JS (2012). High-resolution view of the yeast meiotic program revealed by ribosome profiling. Science 335(6068): 552-557.

15. Kronja I, Orr-Weaver TL (2011). Translational regulation of the cell cycle: when, where, how and why? Philosophical transactions of the Royal Society of London Series B, Biological sciences 366(1584): 3638-3652.

16. Prescott D, Bender M (1962). Synthesis of RNA and protein during mitosis in mammalian tissue culture cells. Experimental cell research 26(2): 260-268.

17. Stumpf CR, Moreno MV, Olshen AB, Taylor BS, Ruggero D (2013). The translational landscape of the mammalian cell cycle. Molecular cell 52(4): 574-582.

18. Scharff MD, Robbins E (1966). Polyribosome disaggregation during metaphase. Science (New York, NY) 151(3713): 992.

19. Pyronnet S, Sonenberg N (2001). Cell-cycle-dependent translational control. Current opinion in genetics \& development 11(1): 13-18.
20. Williamson D, Scopes A (1961). Protein synthesis and nitrogen uptake in synchronously dividing cultures of Saccharomyces cerevisiae. Journal of the Institute of Brewing 67(1): 39-42.

21. Elliott SG, McLaughlin CS (1978). Rate of macromolecular synthesis through the cell cycle of the yeast Saccharomyces cerevisiae. Proceedings of the National Academy of Sciences of the United States of America 75(9): 4384-4388.

22. Elliott SG, Warner JR, McLaughlin CS (1979). Synthesis of ribosomal proteins during the cell cycle of the yeast Saccharomyces cerevisiae. Journal of bacteriology 137(2): 1048-1050.

23. Shulman RW, Hartwell LH, Warner JR (1973). Synthesis of ribosomal proteins during the yeast cell cycle. Journal of molecular biology 73(4): 513-525.

24. Nagaraj N, Kulak NA, Cox J, Neuhauser N, Mayr K, Hoerning O, Vorm O, Mann M (2012). System-wide perturbation analysis with nearly complete coverage of the yeast proteome by single-shot ultra HPLC runs on a bench top Orbitrap. Molecular \& cellular proteomics : MCP 11(3): M111 013722.

25. Lu P, Vogel C, Wang R, Yao X, Marcotte EM (2007). Absolute protein expression profiling estimates the relative contributions of transcriptional and translational regulation. Nature biotechnology 25(1): 117-124.

26. Futcher B, Latter G, Monardo P, McLaughlin C, Garrels J (1999). A sampling of the yeast proteome. Molecular and cellular biology 19(11): 7357-7368.

27. Spellman PT, Sherlock G, Zhang MQ, Iyer VR, Anders K, Eisen MB, Brown PO, Botstein D, Futcher B (1998). Comprehensive identification of cell cycle-regulated genes of the yeast Saccharomyces cerevisiae by microarray hybridization. Molecular biology of the cell 9(12): 32733297.

28. Futcher B (2002). Transcriptional regulatory networks and the yeast cell cycle. Current opinion in cell biology 14(6): 676-683.

29. Di Talia S, Skotheim JM, Bean JM, Siggia ED, Cross FR (2007). The effects of molecular noise and size control on variability in the budding yeast cell cycle. Nature 448(7156): 947-951.

30. Bryan AK, Engler A, Gulati A, Manalis SR (2012). Continuous and long-term volume measurements with a commercial Coulter counter. PloS one 7(1): e29866.

31. Godin M, Delgado FF, Son S, Grover WH, Bryan AK, Tzur A, Jorgensen $P$, Payer K, Grossman AD, Kirschner MW (2010). Using buoyant mass to measure the growth of single cells. Nature methods $7(5)$ : 387-390.

32. Conlon I, Raff M (2003). Differences in the way a mammalian cell and yeast cells coordinate cell growth and cell-cycle progression. Journal of biology 2(1): 7 .

33. Echave $\mathrm{P}$, Conlon IJ, Lloyd AC (2007). Cell size regulation in mammalian cells. Cell cycle (Georgetown, Tex) 6(2): 218-224.

34. Grewal SS, Edgar BA (2003). Controlling cell division in yeast and animals: does size matter? Journal of biology 2(1): 5 .

35. Hartwell LH, Unger MW (1977). Unequal division in Saccharomyces cerevisiae and its implications for the control of cell division. The Journal of cell biology $75(2$ Pt 1): 422-435. 
36. Eser U, Falleur-Fettig M, Johnson A, Skotheim JM (2011). Commitment to a cellular transition precedes genome-wide transcriptional change. Molecular cell 43(4): 515-527.

37. Doncic A, Falleur-Fettig M, Skotheim Jan M (2011). Distinct Interactions Select and Maintain a Specific Cell Fate. Molecular cell 43(4): 528-539.

38. Costanzo M, Nishikawa JL, Tang X, Millman JS, Schub O, Breitkreuz K, Dewar D, Rupes I, Andrews B, Tyers M (2004). CDK activity antagonizes Whi5, an inhibitor of $\mathrm{G} 1 / \mathrm{S}$ transcription in yeast. Cell 117(7): 899-913.

39. de Bruin RA, McDonald WH, Kalashnikova TI, Yates J, 3rd, Wittenberg $C$ (2004). Cln3 activates G1-specific transcription via phosphorylation of the SBF bound repressor Whi5. Cell 117(7): 887-898.

40. Sonenberg N, Hinnebusch AG (2009). Regulation of translation initiation in eukaryotes: mechanisms and biological targets. Cell 136(4): 731-745.

41. Hershey JW, Sonenberg N, Mathews MB (2012). Principles of translational control: an overview. Cold Spring Harbor perspectives in biology 4(12).

42. Kertesz M, Wan Y, Mazor E, Rinn JL, Nutter RC, Chang HY, Segal E (2010). Genome-wide measurement of RNA secondary structure in yeast. Nature 467(7311): 103-107.

43. Ingolia NT, Ghaemmaghami S, Newman JR, Weissman JS (2009). Genome-wide analysis in vivo of translation with nucleotide resolution using ribosome profiling. Science 324(5924): 218-223.

44. Hood HM, Neafsey DE, Galagan J, Sachs MS (2009). Evolutionary roles of upstream open reading frames in mediating gene regulation in fungi. Annual review of microbiology 63(385-409.

45. Altmann M, Trachsel H (1989). Altered mRNA cap recognition activity of initiation factor $4 \mathrm{E}$ in the yeast cell cycle division mutant cdc33. Nucleic acids research 17(15): 5923-5931.

46. Brenner C, Nakayama N, Goebl M, Tanaka K, Toh-e A, Matsumoto $K$ (1988). CDC33 encodes mRNA cap-binding protein elF-4E of Saccharomyces cerevisiae. Molecular and cellular biology 8(8): 3556-3559.

47. Naranda T, MacMillan SE, Hershey JW (1994). Purified yeast translational initiation factor elF-3 is an RNA-binding protein complex that contains the PRT1 protein. The Journal of biological chemistry 269(51): 32286-32292.

48. Keierleber C, Wittekind M, Qin SL, McLaughlin CS (1986). Isolation and characterization of PRT1, a gene required for the initiation of protein biosynthesis in Saccharomyces cerevisiae. Molecular and cellular biology 6(12): 4419-4424.

49. Hanic-Joyce PJ, Johnston GC, Singer RA (1987). Regulated arrest of cell proliferation mediated by yeast prt1 mutations. Experimental cell research 172(1): 134-145.

50. Bedard DP, Johnston GC, Singer RA (1981). New mutations in the yeast Saccharomyces cerevisiae affecting completion of "start". Current genetics 4(3): 205-214.

51. Unger MW, Hartwell LH (1976). Control of cell division in Saccharomyces cerevisiae by methionyl-tRNA. Proceedings of the National Academy of Sciences of the United States of America 73(5): 16641668.

52. Yu L, Pena Castillo L, Mnaimneh S, Hughes TR, Brown GW (2006). A survey of essential gene function in the yeast cell division cycle. Molecular biology of the cell 17(11): 4736-4747.

53. Loewith $R$, Hall MN (2011). Target of rapamycin (TOR) in nutrient signaling and growth control. Genetics 189(4): 1177-1201.
54. Ma XM, Blenis J (2009). Molecular mechanisms of mTOR-mediated translational control. Nature reviews Molecular cell biology 10(5): 307-318.

55. Wicker LS, Boltz RC, Matt V, Nichols EA, Peterson LB, Sigal NH (1990). Suppression of B cell activation by cyclosporin A, FK506 and rapamycin. European journal of immunology 20(10): 2277-2283.

56. Zoncu R, Efeyan A, Sabatini DM (2010). mTOR: from growth signal integration to cancer, diabetes and ageing. Nature reviews Molecular cell biology 12(1): 21-35.

57. Heitman J, Movva NR, Hall MN (1991). Targets for cell cycle arrest by the immunosuppressant rapamycin in yeast. Science 253(5022): 905-909.

58. Barbet NC, Schneider U, Helliwell SB, Stansfield I, Tuite MF, Hall MN (1996). TOR controls translation initiation and early G1 progression in yeast. Molecular biology of the cell 7(1): 25-42.

59. Shahbazian D, Roux PP, Mieulet V, Cohen MS, Raught B, Taunton J, Hershey JW, Blenis J, Pende M, Sonenberg N (2006). The mTOR/PI3K and MAPK pathways converge on elF4B to control its phosphorylation and activity. The EMBO journal 25(12): 2781-2791.

60. Cherkasova VA, Hinnebusch AG (2003). Translational control by TOR and TAP42 through dephosphorylation of elF2alpha kinase GCN2. Genes \& development 17(7): 859-872.

61. Danaie $P$, Altmann M, Hall M, Trachsel H, Helliwell S (1999). CLN3 expression is sufficient to restore G1-to-S-phase progression in Saccharomyces cerevisiae mutants defective in translation initiation factor elF4E. Biochem J 340:135-141.

62. Cai $Y$, Futcher B (2013). Effects of the yeast RNA-binding protein Whi3 on the half-life and abundance of CLN3 mRNA and other targets. PloS one 8(12): e84630.

63. Polymenis M, Schmidt EV (1997). Coupling of cell division to cell growth by translational control of the G1 cyclin CLN3 in yeast. Genes \& development 11(19): 2522-2531.

64. Gallego C, Garí E, Colomina N, Herrero E, Aldea M (1997). The Cln3 cyclin is down-regulated by translational repression and degradation during the $\mathrm{G} 1$ arrest caused by nitrogen deprivation in budding yeast. The EMBO journal 16(23): 7196-7206.

65. Nash R, Tokiwa G, Anand S, Erickson K, Futcher AB (1988). The $\mathrm{WHI} 1+$ gene of Saccharomyces cerevisiae tethers cell division to cell size and is a cyclin homolog. The EMBO journal 7(13): 4335-4346.

66. Cross FR (1988). DAF1, a mutant gene affecting size control, pheromone arrest, and cell cycle kinetics of Saccharomyces cerevisiae. Molecular and cellular biology 8(11): 4675-4684.

67. Di Talia S, Wang H, Skotheim JM, Rosebrock AP, Futcher B, Cross FR (2009). Daughter-Specific Transcription Factors Regulate Cell Size Control in Budding Yeast. PLoS biology 7(10): e1000221.

68. Mackay VL, Mai B, Waters L, Breeden LL (2001). Early Cell Cycle Box-Mediated Transcription ofCLN3 and SWI4 Contributes to the Proper Timing of the G1-to-S Transition in Budding Yeast. Molecular and cellular biology 21(13): 4140-4148.

69. Tyers M, Tokiwa G, Nash R, Futcher B (1992). The Cln3-Cdc28 kinase complex of $\mathrm{S}$. cerevisiae is regulated by proteolysis and phosphorylation. The EMBO journal 11(5): 1773-1784.

70. Tyers M, Tokiwa G, Futcher B (1993). Comparison of the Saccharomyces cerevisiae G1 cyclins: Cln3 may be an upstream activator of $\mathrm{Cln} 1, \mathrm{Cln} 2$ and other cyclins. The EMBO journal 12(5): 1955-1968.

71. Thorburn RR, Gonzalez C, Brar GA, Christen S, Carlile TM, Ingolia NT, Sauer U, Weissman JS, Amon A (2013). Aneuploid yeast strains exhibit defects in cell growth and passage through START. Molecular biology of the cell $24(9)$ : $1274-1289$. 
72. Zapata J, Dephoure N, MacDonough T, Yu Y, Parnell EJ, Mooring M, Gygi SP, Stillman DJ, Kellogg DR (2014). PP2ARts1 is a master regulator of pathways that control cell size. The Journal of cell biology 204(3): 359-376.

73. Gopfert U, Kullmann M, Hengst L (2003). Cell cycle-dependent translation of p27 involves a responsive element in its 5'-UTR that overlaps with a uORF. Human molecular genetics 12(14): 1767-1779.

74. Hengst L, Reed SI (1996). Translational control of p27Kip1 accumulation during the cell cycle. Science 271(5257): 1861-1864.

75. Millard SS, Vidal A, Markus M, Koff A (2000). A U-rich element in the $5^{\prime}$ untranslated region is necessary for the translation of p27 mRNA. Molecular and cellular biology 20(16): 5947-5959.

76. Miskimins WK, Wang G, Hawkinson M, Miskimins R (2001). Control of cyclin-dependent kinase inhibitor p27 expression by capindependent translation. Molecular and cellular biology 21(15): 49604967.

77. Kullmann M, Göpfert U, Siewe B, Hengst L (2002). ELAV/Hu proteins inhibit p27 translation via an IRES element in the p27 5' UTR. Genes \& development 16(23): 3087-3099.

78. Dwyer EJC, Lai H, MacDonald RC, Salvato MS, Borden KL (2000). The lymphocytic choriomeningitis virus RING protein $Z$ associates with eukaryotic initiation factor $4 \mathrm{E}$ and selectively represses translation in a RING-dependent manner. Journal of virology 74(7): 3293-3300.

79. Chen J, Feilotter HE, Paré GC, Zhang X, Pemberton JG, Garady C, Lai D, Yang X, Tron VA (2010). MicroRNA-193b represses cell proliferation and regulates cyclin D1 in melanoma. The American journal of pathology 176(5): 2520-2529.

80. Yu Z, Wang C, Wang M, Li Z, Casimiro MC, Liu M, Wu K, Whittle J, Ju X, Hyslop T (2008). A cyclin D1/microRNA 17/20 regulatory feedback loop in control of breast cancer cell proliferation. The Journal of cell biology 182(3): 509-517.

81. Lai M-C, Chang W-C, Shieh S-Y, Tarn W-Y (2010). DDX3 regulates cell growth through translational control of cyclin E1. Molecular and cellular biology 30(22): 5444-5453.

82. Grey F, Tirabassi R, Meyers H, Wu G, McWeeney S, Hook L, Nelson JA (2010). A viral microRNA down-regulates multiple cell cycle genes through mRNA 5' UTRs. Plos pathogens 6(6): e1000967.

83. Grallert B, Kearsey SE, Lenhard M, Carlson CR, Nurse P, Boye E, Labib $K$ (2000). A fission yeast general translation factor reveals links between protein synthesis and cell cycle controls. Journal of cell science $113(8)$ : 1447-1458.

84. Tarn W-Y, Lai M-C (2011). Translational control of cyclins. Cell division 6(5).

85. Popolo L, Vanoni M, Alberghina L (1982). Control of the yeast cell cycle by protein synthesis. Experimental cell research 142(1): 69-78.

86. Moore SA (1988). Kinetic evidence for a critical rate of protein synthesis in the Saccharomyces cerevisiae yeast cell cycle. The Journal of biological chemistry 263(20): 9674-9681.

87. Ko H, Moore S (1990). Kinetic characterization of a prestart cell division control step in yeast. Implications for the mechanism of alpha-factor-induced division arrest. Journal of Biological Chemistry 265(35): 21652-21663.

88. Obrig TG, Culp WJ, McKeehan WL, Hardesty B (1971). The mechanism by which cycloheximide and related glutarimide antibiotics inhibit peptide synthesis on reticulocyte ribosomes. Journal of Biological Chemistry 246(1): 174-181.
89. Jorgensen P, Rupes I, Sharom JR, Schneper L, Broach JR, Tyers M (2004). A dynamic transcriptional network communicates growth potential to ribosome synthesis and critical cell size. Genes \& development 18(20): 2491-2505.

90. Rossow PW, Riddle VG, Pardee AB (1979). Synthesis of labile, serum-dependent protein in early G1 controls animal cell growth. Proceedings of the National Academy of Sciences of the United States of America 76(9): 4446-4450.

91. Brooks R (1977). Continuous protein synthesis is required to maintain the probability of entry into S phase. Cell 12(1): 311-317.

92. Maaløe O, Kjeldgaard NO (1966). Control of macromolecular synthesis. W.A. Benjamin, Inc., New York.

93. Maaløe O (1979). Regulation of the protein-synthesizing machinery-ribosomes, tRNA, factors, and so on. Biological regulation and development. Springer; pp 487-542.

94. Kaczanowska M, Rydén-Aulin M (2007). Ribosome biogenesis and the translation process in Escherichia coli. Microbiology and Molecular Biology Reviews 71(3): 477-494.

95. Lovmar M, Ehrenberg M (2006). Rate, accuracy and cost of ribosomes in bacterial cells. Biochimie 88(8): 951-961.

96. Waldron C, Lacroute $F$ (1975). Effect of growth rate on the amounts of ribosomal and transfer ribonucleic acids in yeast. Journal of bacteriology 122(3): 855-865.

97. Boehlke K, Friesen J (1975). Cellular content of ribonucleic acid and protein in Saccharomyces cerevisiae as a function of exponential growth rate: calculation of the apparent peptide chain elongation rate. Journal of bacteriology 121(2): 429-433.

98. Ju Q, Warner JR (1994). Ribosome synthesis during the growth cycle of Saccharomyces cerevisiae. Yeast 10(2): 151-157.

99. Warner JR, Gorenstein C (1978). Yeast has a true stringent response. Nature 275(5678): 338-339.

100. Wapinski I, Pfiffner J, French C, Socha A, Thompson DA, Regev A (2010). Gene duplication and the evolution of ribosomal protein gene regulation in yeast. Proceedings of the National Academy of Sciences 107(12): 5505-5510.

101. Giaever G, Chu AM, Ni L, Connelly C, Riles L, Veronneau S, Dow S, Lucau-Danila A, Anderson K, Andre B, Arkin AP, Astromoff A, ElBakkoury M, Bangham R, Benito R, Brachat S, Campanaro S, Curtiss M, Davis K, Deutschbauer A, Entian KD, Flaherty P, Foury F, Garfinkel DJ, Gerstein M, Gotte D, Guldener U, Hegemann JH, Hempel S, Herman Z, et al. (2002). Functional profiling of the Saccharomyces cerevisiae genome. Nature 418(6896): 387-391.

102. Jorgensen P, Nishikawa JL, Breitkreutz BJ, Tyers M (2002). Systematic identification of pathways that couple cell growth and division in yeast. Science 297(5580): 395-400.

103. Zhang J, Schneider C, Ottmers L, Rodriguez R, Day A, Markwardt J, Schneider BL (2002). Genomic scale mutant hunt identifies cell size homeostasis genes in S. cerevisiae. Current biology : CB 12(23): 19922001.

104. Hoose SA, Rawlings JA, Kelly MM, Leitch MC, Ababneh QO, Robles JP, Taylor D, Hoover EM, Hailu B, McEnery KA, Downing SS, Kaushal D, Chen Y, Rife A, Brahmbhatt KA, Smith R, 3rd, Polymenis M (2012). A systematic analysis of cell cycle regulators in yeast reveals that most factors act independently of cell size to control initiation of division. PLoS genetics 8(3): e1002590.

105. Ruggero D, Pandolfi PP (2003). Does the ribosome translate cancer? Nature Reviews Cancer 3(3): 179-192. 
106. Amsterdam A, Sadler KC, Lai K, Farrington S, Bronson RT, Lees JA, Hopkins N (2004). Many ribosomal protein genes are cancer genes in zebrafish. PLoS biology 2(5): e139.

107. Lin JI, Mitchell NC, Kalcina M, Tchoubrieva E, Stewart MJ, Marygold SJ, Walker CD, Thomas G, Leevers SJ, Pearson RB (2011). Drosophila ribosomal protein mutants control tissue growth nonautonomously via effects on the prothoracic gland and ecdysone. PLoS genetics 7(12): e1002408.

108. Bernstein KA, Bleichert F, Bean JM, Cross FR, Baserga SJ (2007). Ribosome biogenesis is sensed at the Start cell cycle checkpoint. Molecular biology of the cell 18(3): 953-964.

109. Soifer I, Barkai N (2014). Systematic identification of cell size regulators in budding yeast. Molecular systems biology 10(11).

110. Thapa M, Bommakanti A, Shamsuzzaman M, Gregory B, Samsel L, Zengel JM, Lindahl $L$ (2013). Repressed synthesis of ribosomal proteins generates protein-specific cell cycle and morphological phenotypes. Molecular biology of the cell 24(23): 3620-3633.

111. He C, Tsuchiyama SK, Nguyen QT, Plyusnina EN, Terrill SR, Sahibzada S, Patel B, Faulkner AR, Shaposhnikov MV, Tsuchiya M, Kaeberlein M, Moskalev AA, Kennedy BK, Polymenis M (2014). Enhanced longevity by ibuprofen, conserved in multiple species, occurs in yeast through inhibition of tryptophan import. PLoS genetics: 10(12): e1004860.

112. Komili S, Farny NG, Roth FP, Silver PA (2007). Functional specificity among ribosomal proteins regulates gene expression. Cell 131(3): 557-571.

113. O'Leary MN, Schreiber KH, Zhang Y, Duc A-CE, Rao S, Hale JS, Academia EC, Shah SR, Morton JF, Holstein CA (2013). The ribosomal protein rpl22 controls ribosome composition by directly repressing expression of its own paralog, rpl22/1. PLoS genetics 9(8): e1003708.

114. Gilbert WV (2011). Functional specialization of ribosomes? Trends in biochemical sciences 36(3): 127-132.

115. Steffen KK, MacKay VL, Kerr EO, Tsuchiya M, Hu D, Fox LA, Dang $\mathrm{N}$, Johnston ED, Oakes JA, Tchao BN (2008). Yeast life span extension by depletion of 60 s ribosomal subunits is mediated by Gcn4. Cell 133(2): 292-302.

116. Mclntosh KB, Warner JR (2007). Yeast ribosomes: variety is the spice of life. Cell 131(3): 450-451.

117. Warner JR, Mclntosh KB (2009). How common are extraribosomal functions of ribosomal proteins? Molecular cell 34(1): 3-11.

118. White-Gilbertson S, Kurtz DT, Voelkel-Johnson C (2009). The role of protein synthesis in cell cycling and cancer. Molecular oncology 3(5): 402-408.

119. Tuller T, Veksler-Lublinsky I, Gazit N, Kupiec M, Ruppin E, ZivUkelson $M$ (2011). Composite effects of gene determinants on the translation speed and density of ribosomes. Genome biology 12(11): R110.

120. Plotkin JB, Kudla G (2010). Synonymous but not the same: the causes and consequences of codon bias. Nature Reviews Genetics 12(1): 32-42.

121. Siwiak M, Zielenkiewicz P (2010). A comprehensive, quantitative, and genome-wide model of translation. PLoS computational biology 6(7): e1000865.
122. Tuller T, Waldman YY, Kupiec M, Ruppin E (2010). Translation efficiency is determined by both codon bias and folding energy. Proceedings of the National Academy of Sciences 107(8): 3645-3650.

123. Qian W, Yang J-R, Pearson NM, Maclean C, Zhang J (2012). Balanced codon usage optimizes eukaryotic translational efficiency. PLoS genetics 8(3): e1002603.

124. Charneski CA, Hurst LD (2013). Positively charged residues are the major determinants of ribosomal velocity. PLoS biology 11(3): e1001508.

125. Wallace EW, Airoldi EM, Drummond DA (2013). Estimating selection on synonymous codon usage from noisy experimental data. Molecular biology and evolution: mst051.

126. Yang J-R, Chen X, Zhang J (2014). Codon-by-codon modulation of translational speed and accuracy via mRNA folding. PLoS biology 12(7): e1001910.

127. Gardin J, Yeasmin R, Yurovsky A, Cai Y, Skiena S, Futcher B (2014). Measurement of average decoding rates of the 61 sense codons in vivo. elife 3:e03735.

128. Fredrick K, Ibba M (2010). How the sequence of a gene can tune its translation. Cell 141(2): 227-229.

129. Tuller T, Carmi A, Vestsigian K, Navon S, Dorfan Y, Zaborske J, Pan T, Dahan O, Furman I, Pilpel Y (2010). An evolutionarily conserved mechanism for controlling the efficiency of protein translation. Cell 141(2): 344-354.

130. Cannarozzi G, Schraudolph NN, Faty M, von Rohr P, Friberg MT, Roth AC, Gonnet P, Gonnet G, Barral Y (2010). A role for codon order in translation dynamics. Cell 141(2): 355-367.

131. Frenkel-Morgenstern M, Danon T, Christian T, Igarashi T, Cohen $L$, Hou YM, Jensen $L$ (2012). Genes adopt non-optimal codon usage to generate cell cycle-dependent oscillations in protein levels. Molecular systems biology $8(1)$.

132. Ingolia NT, Lareau LF, Weissman JS (2011). Ribosome profiling of mouse embryonic stem cells reveals the complexity and dynamics of mammalian proteomes. Cell 147(4): 789-802.

133. Pop C, Rouskin S, Ingolia NT, Han L, Phizicky EM, Weissman JS, Koller D (2014). Causal signals between codon bias, mRNA structure, and the efficiency of translation and elongation. Molecular systems biology 10(12).

134. Goranov Al, Amon A (2010). Growth and division-not a one-way road. Current opinion in cell biology 22(6): 795-800.

135. Goranov Al, Cook M, Ricicova M, Ben-Ari G, Gonzalez C, Hansen $C$, Tyers $M$, Amon A (2009). The rate of cell growth is governed by cell cycle stage. Genes \& development 23(12): 1408-1422.

136. Sachs $A B$, Davis RW (1989). The poly $(A)$ binding protein is required for poly $(A)$ shortening and $60 \mathrm{~S}$ ribosomal subunit-dependent translation initiation. Cell 58(5): 857-867.

137. Prendergast JA, Murray LE, Rowley A, Carruthers DR, Singer RA, Johnston GC (1990). Size selection identifies new genes that regulate Saccharomyces cerevisiae cell proliferation. Genetics 124(1): 81-90.

138. Bernstein KA, Baserga SJ (2004). The small subunit processome is required for cell cycle progression at G1. Molecular biology of the cell 15(11): 5038-5046. 